\title{
Clinical Molecular Imaging with Radiotracers: Current Status
}

\author{
Michael M. Graham \\ Department of Radiology, University of lowa, lowa City, lowa, USA
}

\section{Key Words}

Molecular imaging $\cdot$ Nuclear medicine $\cdot$ Radiotracers creasingly important to determine whether a treatment that is targeted to a specific metabolic pathway or receptor is likely to be successful.

Copyright $\odot 2011$ S. Karger AG, Basel

\begin{abstract}
Molecular imaging is defined as the visualization, characterization, and measurement of biological processes at the molecular and cellular levels in humans and other living systems. Most clinical molecular imaging is currently done using radioisotope-labeled agents to define the activity of various metabolic pathways in vivo or to determine the distribution and density of various receptors relevant to human disease. This paper briefly reviews most of the commonly used radiopharmaceuticals in nuclear medicine, as well as newer agents that are likely to become available in the near future. The metabolic pathways include those relevant to the thyroid, parathyroid, heart, brain, bones, kidneys, liver, pancreas, adrenals and tumor. The receptor systems include agents useful in evaluating movement disorders, dementia, cardiac sympathetic enervation and neoangiogenesis. Receptor systems relevant to tumors include somatostatin receptors (neuroendocrine tumors), prostate-specific membrane antigen, carbonic anhydrase IX (renal cancer), and CD20 (lymphoma). These agents, and newer agents that are being developed, are likely to become critical in the development of personalized medicine, where it will become in-
\end{abstract}

\section{Introduction}

Molecular imaging is the visualization, characterization, and measurement of biological processes at the molecular and cellular levels in humans and other living systems [1]. Molecular imaging typically includes two- or three-dimensional imaging as well as quantitation over time. The technologies involved in molecular imaging include nuclear medicine, along with both positron emission tomography (PET) and single-photon emission computed tomography (SPECT) imaging, magnetic resonance spectroscopy, optical imaging, and ultrasound, which is now beginning to use microbubbles to create molecular images.

The discussion in this paper is confined to the nuclear medicine aspects of molecular imaging because they reflect the author's major area of knowledge, and because at this time most molecular imaging is done using a wide array of radiotracers. The tracers discussed below have been used in human studies, but this is definitely an in-

\section{KARGER \\ Fax +4161306 1234 \\ E-Mail karger@karger.ch}

www.karger.com (c) 2011 S. Karger AG, Basel

1011-7571/12/0213-0197\$38.00/0

Accessible online at:

www.karger.com/mpp
Michael M. Graham

Department of Radiology 3863 JPP, University of Iowa

200 Hawkins Drive

Iowa City, IA 52242 (USA)

Tel. +1 319356 4302, E-Mail michael-graham@uiowa.edu 
complete listing of all the molecular imaging that has been done in humans. Rather, it is a snapshot of the current status of the field and briefly discusses most of the molecular-imaging agents that are in current use or appear to be likely to enter clinical use in the next few years. There are far more molecular-imaging agents that have been studied in animals and eventually may become clinically useful, but these are not reviewed in this paper.

Nuclear medicine studies can be characterized into three major groups: flow, metabolism and receptor ligands (fig. 1). Although the studies that fall within the 'flow' category comprise a significant and important fraction of nuclear medicine studies done today, these studies do not qualify as 'molecular imaging' and will not be discussed further.

The agents used for metabolic imaging are generally small molecules, such as glucose or amino acids, which are rapidly taken up into cells by transporters and metabolized in the cytoplasm. Many of the agents are analogs of the native small molecules and are designed to undergo limited metabolism and then be retained within the cell. This process is called 'metabolic trapping' and is an important goal in the design and selection of metabolic imaging agents.

The agents used for receptor-based imaging are generally either antibodies (or fragments of antibodies), oligopeptides or small molecules. Other types of molecules, such as RNA aptamers, are being developed in the laboratory, but are many years away from widespread use in humans. All of the receptor-based ligands specifically bind to receptors. Selection of an optimum agent is based on several characteristics, including receptor specificity: only binds to one receptor with minimal nonspecific binding; affinity: how tightly the ligand is bound to the receptor; metabolism: ideally the ligand is not metabolized; and clearance: how rapidly the ligand clears from the blood. Currently, there are relatively few radioisotope-labeled receptor-based tracers available for clinical use. However, hundreds of potential receptors have been identified in a wide variety of diseases. This area of molecular imaging represents the area with the greatest potential for growth over the next several years.

\section{Metabolism-Based Molecular Imaging}

\section{Atomic Elements}

The simplest radiotracers used for metabolic imaging are several radioactive isotopes that are administered as the element, without labeling to any compound. These include iodine $\left({ }^{123} \mathrm{I}\right.$ and $\left.{ }^{131} \mathrm{I}\right)$, gallium $\left({ }^{67} \mathrm{Ga}\right.$ and $\left.{ }^{68} \mathrm{Ga}\right)$, indium $\left({ }^{111} \mathrm{In}\right)$, thallium $\left({ }^{201} \mathrm{Tl}\right)$, rubidium $\left({ }^{82} \mathrm{Rb}\right)$ and strontium $\left({ }^{89} \mathrm{Sr}\right)$. The noble gases krypton and xenon are used for ventilation imaging, but since these gases are not metabolized, they will not be included in the discussion.

The sodium iodide symporter in the thyroid gland takes up iodine into the thyroid. When ${ }^{123} \mathrm{I}$ or ${ }^{131} \mathrm{I}$ is administered orally, it is rapidly absorbed, distributes throughout the body via the vasculature and is taken up and concentrated in the thyroid. This is clinically useful for diagnosing thyroid disease, such as Graves' disease, autonomous nodules and cancer. ${ }^{131}$ I in larger quantities is used in the treatment of both Graves' disease and thyroid cancer. It is remarkably effective since the concentration of radioiodine is far higher in thyroid tissue and thyroid cancer than in any other site in the body.

When ${ }^{67} \mathrm{Ga}$, as gallium citrate, is injected intravenously, it is promptly chelated by transferrin. The subsequent behavior of gallium reflects the behavior of transferrin. ${ }^{67} \mathrm{Ga}$ has been used clinically since the early 1970 s for diagnosis and follow-up of tumor and infection. It was particularly useful for lymphoma. In recently years, its use has diminished, although it is still available. ${ }^{68} \mathrm{Ga}$, a positron emitter, is emerging as a useful agent for labeling receptor ligands (see below), but has also been used by itself, injected intravenously and bound to transferrin, and has been used to measure vascular permeability in the lung [2]. Because of the short half-life of ${ }^{68} \mathrm{Ga}(68 \mathrm{~min})$, it does not seem to be very useful otherwise, when used by itself.

Indium falls directly below gallium in the periodic table (group 3A), and has somewhat similar characteristics. ${ }^{111}$ In, as indium chloride, when injected intravenously behaves like gallium and is chelated by transferrin. ${ }^{111} \mathrm{In}$ chloride has been used as an infection imaging agent and performs very much like ${ }^{67} \mathrm{Ga}$ citrate. Imaging is typically done at 3 days after injection. Because of the clinical success of ${ }^{111}$ In-labeled white blood cells, ${ }^{111}$ In chloride as well as ${ }^{67} \mathrm{Ga}$ citrate are currently used less frequently than they were in the past.

Although thallium falls directly below gallium in the periodic table (group 3A), it behaves quite differently. ${ }^{201} \mathrm{Tl}$ uptake is mediated by the $\mathrm{Na}^{+}-\mathrm{K}^{+}$pump in both myocytes and tumor cells. In the heart, because of the high extraction fraction, it is a marker of myocardial blood flow. In tumors, it is a marker of tumor viability and it is used in imaging brain tumors to address the question of radionecrosis versus recurrence [3]. It is successful in assessing the viability of brain tumors because there is essentially no uptake in normal brain, resulting in a high target-to-background ratio. 


\begin{tabular}{|c|c|c|}
\hline \multicolumn{3}{|c|}{ Single-photon radiopharmaceutical studies } \\
\hline Flow & Metabolism & Receptors \\
\hline Heart & Bone & Somatostatin \\
\hline 99mTc-sestamibi & 99mTc-MDP and HDP & ${ }^{111}$ In-octreotide \\
\hline${ }^{99 \mathrm{~m}} \mathrm{Tc}$-tetrofosmin, ${ }^{201} \mathrm{TI}$ & Bone pain therapy & ${ }^{99 \mathrm{~m}} \mathrm{Tc}$-depreotide (neuroendocrine tumors) \\
\hline Brain & ${ }^{89} \mathrm{Sr},{ }^{153} \mathrm{Sm}-\mathrm{EDTMP}$ & \\
\hline 99mTc-HMPAO and ECD & Biliary & Norepinephrine reuptake \\
\hline Lung & ${ }^{99 m} \mathrm{Tc}-\mathrm{mebrofenin}$ and disofenin & ${ }^{123} \mathrm{I}$ - and ${ }^{131} \mathrm{I}-\mathrm{MIBG}$ \\
\hline${ }^{99 \mathrm{~m}} \mathrm{Tc}-\mathrm{MAA}$ and aerosol, ${ }^{133} \mathrm{Xe}$ & Renal & (pheochromocytoma and heart failure) \\
\hline Stomach & 99mTc-MAG-3, DTPA and DMSA & Prostate-specific membrane antigen \\
\hline${ }_{99 \mathrm{~m} T c-s u l f u r}$ colloid and eggs & Heart & ${ }^{111}$ In-capromab pendetide (prostate cancer) \\
\hline Lymphatic & ${ }^{123}$ I-BMIPP & \\
\hline Filtered ${ }^{99 \mathrm{~m}} \mathrm{Tc}$-sulfur colloid & Thyroid & CD-20 receptors in lymphoma \\
\hline Cystography & ${ }^{131} \mathrm{I},{ }^{123} \mathrm{I},{ }^{99 \mathrm{~m}} \mathrm{Tc}-$ pertechnetate & ${ }^{111}$ In- and ${ }^{90} Y$-ibritumomab \\
\hline $99 \mathrm{~m}$ Tc-sulfur colloid in saline & Parathyroid adenoma & ${ }^{131}$ I-tositumomab \\
\hline CSF shunts & 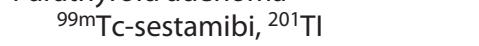 & \\
\hline${ }^{99 m}$ Tc-DTPA and pertechnetate & Infection & Cell trafficking \\
\hline Gl bleeding & Labeled white blood cells with & Directly labeled cells \\
\hline${ }^{99 \mathrm{~m}}$ Tc-labeled red blood cells & ${ }^{111}$ In or HMPAO & ${ }^{111}$ In-labeled white blood cells \\
\hline Gated blood pool & Adrenal & Cells labeled with a reporter gene \\
\hline${ }^{99 m}$ Tc-labeled red blood cells & ${ }^{134}$ |-iodocholesterol & T cells, stem cells, macrophages \\
\hline Dacrocystography & Basal ganglia & \\
\hline 99mTc-DTPA & ${ }^{123}$ I-DaTscan & \\
\hline \multicolumn{3}{|c|}{ Positron-emitting radiopharmaceutical studies } \\
\hline Flow & Metabolism & Receptors \\
\hline Heart & Tumor & Somatostatin \\
\hline${ }^{13} \mathrm{~N}$-ammonia, ${ }^{82} \mathrm{Rb}$ & ${ }^{18} \mathrm{~F}$-fluorodeoxyglucose & ${ }^{68} \mathrm{Ga}-\mathrm{DOTATOC}$ \\
\hline${ }^{18} \mathrm{~F}-\mathrm{BMS} 747158$ & ${ }^{18} \mathrm{~F}$-fluorothymidine & ${ }^{68} \mathrm{Ga}$-DOTATATE (neuroendocrine tumors) \\
\hline Brain & ${ }^{18} \mathrm{~F}-\mathrm{DOPA}$ & \\
\hline \multirow[t]{15}{*}{${ }^{15} \mathrm{O}$-water } & ${ }^{11} \mathrm{C}$-acetate & Melanocortin \\
\hline & ${ }^{11} \mathrm{C}$-methionine & ${ }^{68} \mathrm{Ga}-\alpha-\mathrm{MSH}$ \\
\hline & ${ }^{11} \mathrm{C}$ - and ${ }^{18} \mathrm{~F}$-choline & ${ }^{64} \mathrm{Cu}-\alpha-\mathrm{MSH}$ (melanoma) \\
\hline & Heart & \\
\hline & ${ }^{18} \mathrm{~F}$-fluorodeoxyglucose & $\alpha \mathrm{V} \beta 3$ integrin \\
\hline & ${ }^{11} \mathrm{C}$-acetate & ${ }^{18} \mathrm{~F}$-galacto-RGD (tumor angiogenesis) \\
\hline & ${ }^{11} \mathrm{C}$-palmitate & \\
\hline & Brain & Carbonic anhydrate IX \\
\hline & ${ }^{11} \mathrm{C}-\mathrm{FDOPA}$ & ${ }^{124} \mid$-redectane (renal cell carcinoma) \\
\hline & ${ }^{11} \mathrm{C}$-raclopride & \\
\hline & ${ }^{11} \mathrm{C}$-Pittsburgh compound B & \\
\hline & ${ }^{18} \mathrm{~F}-\mathrm{AV}-45$ & \\
\hline & Hypoxia & \\
\hline & ${ }^{18}$ F-Fluoromisonidazole & \\
\hline & ${ }^{64} \mathrm{Cu}-\mathrm{ATSM}$ & \\
\hline
\end{tabular}

Fig. 1. Summary of the radiotracers either in current use in nuclear medicine or likely to be available in the near future. HMPAO = Hexamethylpropyleneamine oxime; ECD = ethyl cysteinate dimer; $\mathrm{MAA}=$ macro aggregated albumin; DTPA $=$ diethylenetriamine pentaacetate; MDP = methylene diphosphonate; HDP = hydroxymethylene diphosphonate; EDTMP = ethylenediaminetetramethylenephosphonate; MAG-3 = mercapto- acetyltriglycine; DMSA = dimercaptosuccinic acid; $\mathrm{MIBG}=$ metaiodobenzylguanidine; BMIPP $=15$ - $(p$-iodophenyl $)-3 R, S$ methyl pentadecanoic acid; DOTATOC, DOTATATE $=$ agents of the DOTA (1,4,7,10-tetraazacyclododecane-1,4,7,10-tetraacetic acid) chelation group; FDOPA = fluoro-DOPA; ATSM = diacetylbis (N(4)-methylthiosemicarbazone); $\alpha$-MSH = melanocyte stimulating hormone; RGD = arginine-glycine-aspartate. 
Rubidium falls immediately below potassium in the periodic table (group 1A) and behaves quite similarly. It is taken up by the $\mathrm{Na}^{+}-\mathrm{K}^{+}$pump and is used as a marker of myocardial perfusion. Currently, ${ }^{82} \mathrm{Rb}$ (half-life $=75 \mathrm{~s}$ ) is used as a positron-emitting tracer of myocardial blood flow [4]. In the past, other isotopes of rubidium have been studied, i.e. ${ }^{81} \mathrm{Rb},{ }^{84} \mathrm{Rb}$ and ${ }^{86} \mathrm{Rb}$, as well as other elements in the first column of the periodic table, ${ }^{43} \mathrm{~K}$ and ${ }^{129} \mathrm{Cs}$ [5]. None of the latter isotopes are used currently.

Strontium is immediately below calcium in the periodic table (group 2A) and, predictably, behaves very similarly in vivo. Sr-89 chloride is one of two widely available agents used for the treatment of bone pain associated with widespread skeletal metastatic disease. The other agent is ${ }^{153} \mathrm{Sm}$-ethylenediaminetetramethylenephosphonate. Since strontium is an analog of calcium, it is taken up by osteoblasts. In sites of skeletal metastases there is intense osteoblastic activity in an attempt to repair the injured bone. This results in high uptake of all the bonescanning agents, including ${ }^{89} \mathrm{Sr}$. Although the real target is the nearby tumor and not the osteoblasts, it has been shown that a definite tumor effect occurs with ${ }^{89} \mathrm{Sr}$ and pain is often significantly relieved although only temporarily [6].

\section{Molecular Tracers of Metabolism}

The radiotracers, discussed below, are bound to a wide variety of organic molecules that are metabolized. These tracers are organized by organ or disease.

Heart

Myocardial imaging is mainly used to assess the distribution of perfusion. However, there is an increasing awareness that molecular imaging of metabolism and receptor density is useful for characterizing a number of relevant phenomena, including congestive heart failure, hibernating myocardium, unstable plaque and neoangiogenesis.

${ }^{123}$ I-metaiodobenzylguanidine (MIBG), an analog of norepinephrine, can be used to assess sympathetic enervation of the heart by measuring uptake and washout. The washout rate in patients with heart failure is a strong prognostic predictor of sudden cardiac death. Based on this observation, it has been suggested that MIBG cardiac imaging should be used to determine which patients need implantable defibrillators [7].

Hibernating myocardium is characterized by resting ischemia and decreased contractility. If the ischemia is corrected, contractility usually significantly improves. ${ }^{18} \mathrm{~F}$-fluorodeoxyglucose (FDG) imaging is currently used to identify viable ischemic myocardium (good FDG uptake in an area of decreased perfusion) [8]. In the past, ${ }^{201} \mathrm{Tl}$ was also used (improved uptake on delayed images compared to initial uptake at rest).

Stunned myocardium occurs when there has been temporary ischemia and, even though perfusion has been restored, function does not return to normal immediately. It is useful to identify stunned myocardium since it is an indication that significant ischemia has occurred in the recent past although perfusion may have normalized. A newer agent ${ }^{123}$ I-15-( $p$-iodophenyl)-3R, $S$-methyl pentadecanoic acid is a fatty acid, whose uptake can identify stunned or hibernating myocardium. It appears that it is likely to be most useful in assessing patients with acute chest pain, even when injected $48 \mathrm{~h}$ after the event [9].

\section{Brain}

${ }^{18}$ F-FDG was initially developed as an agent to study glucose metabolism in the brain [10]. FDG has been used in numerous studies of brain metabolism and continues to be used clinically in the evaluation of epilepsy, dementia and brain neoplasms. Images of patients with partial complex epilepsy, when acquired between seizures, i.e. interictally, show decreased uptake in the area associated with the origin of the seizure [11]. FDG images of subjects with dementia show different patterns of uptake dependent on the type of dementia [12].

Bone

The majority of metabolic bone imaging is done to identify areas of increased new bone formation associated with increased osteoblast activity. Several different phosphonates have been labeled with technetium-99m $\left({ }^{99 \mathrm{~m}} \mathrm{Tc}\right)$ and are used clinically to identify sites of metastatic disease, fracture, osteomyelitis and numerous other disorders [13]. Common to all these disorders is that osteoblastic activity is increased in an effort to repair injured bone. The use of ${ }^{18} \mathrm{~F}$-fluoride bone imaging, using high-energy scanning collimators, preceded that of ${ }^{99 \mathrm{~m}}$ Tc-labeled phosphonates, but was abandoned because of the superior imaging characteristics of ${ }^{99 \mathrm{~m}} \mathrm{Tc}$ [14]. More recently, it has been recognized that ${ }^{18} \mathrm{~F}$-fluoride bone scanning, using PET-CT imaging, yields higher-resolution images and improved accuracy, with a similar radiation dose and at an earlier time after injection than the ${ }^{99 \mathrm{~m}} \mathrm{Tc}$ agents [15]. ${ }^{18} \mathrm{~F}$-fluoride PET imaging also has the capability of quantitating bone blood flow because the arterial-venous extraction fraction is very high. 


\section{Liver}

Many of the commonly used radiotracers show significant uptake in the liver, but relatively few are used to explicitly examine liver metabolism. The most commonly used agents for liver metabolism are the ${ }^{99 \mathrm{~m}} \mathrm{Tc}$-labeled iminodiacetic acid analogs, which are taken up by hepatocytes and handled like bilirubin [16]. These agents can be used to assess overall liver function by quantitating the uptake rate into the liver or the clearance rate from the blood. However, these agents are generally used to assess the status of the gallbladder for the clinical diagnosis of acute or chronic cholecystitis.

The other major aspect of liver metabolism that is commonly studied is the reticuloendothelial function, i.e. phagocytosis. Initially, the radiotracer used was gold$198\left({ }^{198} \mathrm{Au}\right)$ colloid [17]. Gold colloid was replaced by ${ }^{99 \mathrm{~m}} \mathrm{Tc}$-sulfur colloid in the 1970s although other agents, such as ${ }^{111}$ In-colloid, have been investigated more recently [18].

\section{Kidney}

Two of the three commonly used renal radiopharmaceuticals are true metabolic imaging agents. The exception is ${ }^{99 \mathrm{~m}} \mathrm{Tc}$-diethylenetriaminepentaacetic acid (DTPA), which is a glomerular agent and is passively filtered by the glomerulus.

${ }^{99 \mathrm{~m}} \mathrm{Tc}$-mercaptoacetyltriglycine (MAG-3) is taken up and excreted through the proximal tubules [19]. The extraction fraction is relatively high $(0.54-0.62)$. The uptake rate can be used as an index of renal blood flow and also as an indicator of the status of the proximal tubules, i.e. acute tubular necrosis or other causes of tubular injury. ${ }^{99 \mathrm{~m}} \mathrm{Tc}-\mathrm{MAG}-3$ is the most commonly used renal radiopharmaceutical, generally for the detection of renal obstruction.

Another tubular agent, similar in function to MAG-3 is ${ }^{99 \mathrm{~m}} \mathrm{Tc}-\mathrm{L}, \mathrm{L}-\mathrm{e}$ thylenedicysteine (LL-EC) [20]. It was developed during studies of the cerebral perfusion agent ${ }^{99 \mathrm{~m}} \mathrm{Tc}$ L,L-ethylenedicysteine dietheylester ( ${ }^{99 \mathrm{~m} T c-L L-E C D)}$, when it was noted that the major metabolite, LL-EC, had excellent and rapid renal clearance. Its behavior is similar, but not identical, to MAG-3. It is used clinically in some countries although it is not available for clinical use in the USA. Interestingly, an effort has been made to combine

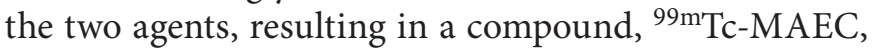
that seems to have higher clearance than MAG-3 [21].

${ }^{99} \mathrm{~m}$ Tc-dimercaptosuccinic acid (DMSA) also is a marker of tubular function although this agent is bound to the proximal tubules and only a small fraction $(4-8 \%$ over the first hour) is excreted into the urine [22]. ${ }^{99 \mathrm{~m}} \mathrm{Tc}$ -
DMSA is primarily used for imaging of renal scarring associated with pylonephritis.

\section{Pancreas}

Metabolic imaging of the pancreas was originally done using selenium-75 $\left({ }^{75} \mathrm{Se}\right)$-selenomethionine [23]. It is presumably a marker of protein synthesis, and thus of exocrine pancreatic function. This agent has been abandoned because of an unacceptably high false-positive rate and because of the poor imaging quality and dosimetry aspects of ${ }^{75} \mathrm{Se}$ (half-life $=120$ days, typical dose $=3 \mu \mathrm{Ci}$ / $\mathrm{kg}$, whole-body radiation dose $=17 \mathrm{mGy}$, multiple gammas from 120 to $400 \mathrm{keV}$ ).

More recently, metabolic imaging of the pancreas has focused on the possibility of quantitation of $\beta$-cell mass. This is of particular interest in conjunction with $\beta$-cell transplantation as a treatment of type 1 diabetes. Several potential radiotracers have been studied, and a number of them show significant promise [24]. One of the best targets seems to be the vesicular monoamine transporter type 2 , which can be imaged with ${ }^{11} \mathrm{C}$-dihydrotetrabenazine, an agent that has also been used as a biomarker of brain dopamine neurons [25].

\section{Parathyroid}

Adenomas in the parathyroid show increased uptake of the myocardial perfusion tracers, sestamibi, tetrofos$\mathrm{min}$ and thallium. The uptake is associated with increased blood flow to the adenomas as well as increased mitochondrial metabolism. A more direct approach to detecting these adenomas takes advantage of the increased protein synthesis that is involved in the overproduction of parathyroid hormone. It is reasonable to expect that amino acid uptake should be increased as a marker of the increased protein synthesis. ${ }^{75} \mathrm{Se}$-selenomethionine was successfully used for parathyroid adenoma imaging beginning in the 1960s, but is no longer available. Imaging was done approximately $2 \mathrm{~h}$ after injection and the targetto-background ratio was very high [26]. More recently, the possibility of using ${ }^{11} \mathrm{C}$-methionine has been examined, and it seems to have high sensitivity [27]. It is possible that labeled amino-acid imaging will become the method of choice in the future although currently sestamibi imaging is the most commonly used approach.

\section{Adrenal}

Uptake of ${ }^{131}$ I-iodocholesterol is a marker of adrenal cortical metabolism, where glucocorticoids and mineralocorticoids are synthesized. Increased uptake is seen in cortisol- and aldosterone-producing adenomas and in 
Cushing's disease. The most successful analog of cholesterol was found to be $6 \beta$-iodomethyl-norcholesterol, also called NP-59. It was developed by the group at the University of Michigan in the 1970s and has been made available to other sites as an investigational agent [28].

\section{Tumor (Including Hypoxia)}

\section{${ }^{18}$ F-Fluorodeoxyglucose}

${ }^{18}$ F-FDG was originally developed to study brain glucose metabolism, but was found to be an excellent tumorimaging agent. FDG is taken up by facilitated transport involving the glucose transporters. It is then phosphorylated to FDG- $6 \mathrm{PO}_{4}$, and since it is charged it is retained in the cell. No further metabolism takes place and it is 'metabolically trapped'. A few tissues, such as liver, have high levels of phosphatase, which allows the FDG to dephosphorylate and diffuse out of the cell, but this does not happen in most tissues, including tumors. Most tumors use glucose avidly and show very high uptake of FDG. FDG has become the dominant radiopharmaceutical in PET oncology imaging [29].

\section{${ }^{18}$ F-Fluorothymidine}

${ }^{18} \mathrm{~F}$-fluorothymidine uptake is a marker of DNA synthesis. The uptake and retention is analogous to those of FDG. It is transported across the cell membrane by facilitated nucleoside transporters and is then phosphorylated by thymidine kinase and trapped. The major role of ${ }^{18} \mathrm{~F}$-fluorothymidine is as an early indicator of response to therapy. A number of small clinical studies have shown significant promise [30], but larger trials are needed before it becomes a widely used clinical tool.

\section{Acetate}

Acetate is a central molecule in metabolism, particularly in the tricarboxylic acid cycle. It also is a major fundamental building block in other metabolic pathways, including cholesterol and heme synthesis. In tumors, most of the acetate taken up is used in the lipid synthesis pathway leading to membrane synthesis. Clinically, ${ }^{11} \mathrm{C}$-acetate shows excellent uptake into several different types of tumors, including prostate cancer. The major role that is anticipated for ${ }^{11} \mathrm{C}$-acetate is in the staging and followup of prostate cancer although the short half-life of ${ }^{11} \mathrm{C}$ (20 min) limits its utility to institutions with cyclotrons and radiochemistry facilities [31].

Although ${ }^{18} \mathrm{~F}$-fluoroacetate has been proposed as a possible longer-lived version of labeled acetate, studies have shown that the metabolism of fluoroacetate is very different from that of acetate [32]. In addition, fluoroacetate is far more toxic than acetate.

\section{Choline}

Choline is a major component of cell membranes in that the outer layer of the bilayer cell membrane is usually made up of phosphatidylcholine. Studies with ${ }^{11} \mathrm{C}$ - and ${ }^{18} \mathrm{~F}$-labeled choline have shown excellent uptake in several types of tumors. Choline imaging has been most useful in prostate cancer [31], and performs very similarly to acetate. ${ }^{18} \mathrm{~F}$-labeled choline is increasingly being used in Europe and Japan to assist in staging and later re-evaluation of patients with prostate cancer. It is not being used in the United States because of intellectual property issues.

\section{Amino Acids}

Several different amino acids have been labeled with ${ }^{11} \mathrm{C}$ for PET imaging of tumor metabolism. Because of the short half-life of ${ }^{11} \mathrm{C}$, the images typically obtained at $45-$ 60 min after injection are primarily a depiction of amino acid transport into the cells, rather than the incorporation of amino acids into protein. Nevertheless, the images are usually regarded as approximate maps of protein synthesis. Since amino acid transport and protein synthetic rates have to be tightly linked, this is a reasonable assumption.

Most of the studies with ${ }^{11} \mathrm{C}$-labeled amino acids have been done with ${ }^{11} \mathrm{C}$-methionine, which has been particularly useful in imaging brain tumors, both primary and metastatic. It is used to assist in radiotherapy treatment planning [33] and in differentiating between radionecrosis and recurrence following radiotherapy [34].

The short half-life of ${ }^{11} \mathrm{C}$ limits the possibility that ${ }^{11} \mathrm{C}$ methionine will become broadly available. ${ }^{18} \mathrm{~F}$-fluoro-LDOPA (FDOPA) provides an attractive alternative. FDO$\mathrm{PA}$ is very similar to phenylalanine, and is taken up by the same amino acid transporters as methionine. FDOPA has been found to be at least as good as ${ }^{11} \mathrm{C}$-methionine in imaging brain tumors [35].

1-Aminocyclobutane carboxylic acid (ACBC), an unnatural amino acid, can be labeled with ${ }^{11} \mathrm{C}$ or ${ }^{18} \mathrm{~F}$ and has been found to be accurate in the assessment of brain tumors [36] and other tumors, including tumors of the prostate [37].

\section{Hypoxia Agents}

Hypoxia is a potential problem in many diseases, such as myocardial infarction, but most of the interest in identification of profoundly hypoxic, but viable tissue is in the 
context of tumors that might be hypoxic. This is because such tumors are markedly radio-resistant, with radiation tolerance as high as 2.5 times that of normoxic tumors. Accurate, quantitative imaging of hypoxic tumors should facilitate accurate targeting of hypoxic tumors to deliver higher radiations doses, for determination of the efficacy of reoxygenation strategies and for stratification of patients for treatment with hypoxic radiosensitizers.

Most of the agents used for imaging hypoxia are nitroimidazoles [38]. These molecules are freely diffusible into almost all tissues, but in hypoxic tissue undergo a two-step reduction that creates a reactive species that binds to nearby macromolecules. After sufficient time to clear unbound activity from normoxic tissue, imaging will reveal the sites of hypoxia. All of the nitroimidazoles behave somewhat similarly, and differ primarily in their oil:water partition coefficients and rates of tissue uptake and clearance. The oldest and best studied of these agents is ${ }^{18} \mathrm{~F}$-fluoromisonidazole (FMISO). More recent agents include ${ }^{18} \mathrm{~F}$-fluoroazomycin-arabinofuranoside (FAZA), ${ }^{18}$ F-fluoroetanidazole (FETA), ${ }^{18} \mathrm{~F}$-fluoroerythronitroimidazole (FETNIM), ${ }^{18}$ F 2-(2-nitro-1H-imidazol-1-yl)$\mathrm{N}-(2,2,3,3,3$-pentafluoropropyl)-acetamide (EF5), a similar molecule ${ }^{18} \mathrm{~F}-\mathrm{EF} 3$, and ${ }^{123} \mathrm{I}$ - and ${ }^{124} \mathrm{I}$-iodoazomycin arabinoside (IAZA). The most prominent nonnitroimidazole agent is diacetyl-bis ( $\mathrm{N}(4)$-methylthiosemicarbazone (ATSM), which can be labeled with any of the positron-emitting isotopes of copper [39]. Many of the early studies with ATSM have been done with ${ }^{60} \mathrm{Cu}$, but ${ }^{64} \mathrm{Cu}$ (half-life $=12.7 \mathrm{~h}$ ) appears to have better characteristics to be used clinically. The binding mechanism of ATSM is somewhat different from that of the nitroimidazoles, but also involves binding following reduction [40].

\section{Receptor Ligand-Based Molecular Imaging}

\section{Brain}

There have been more studies in defining receptor density in the brain than in any other part of the body. These investigations have included binding studies of analogs of dopamine, nicotine, cocaine, opioids, benzodiazepines, amphetamines and many others. It is beyond the scope of this paper to try to review all the receptor studies in the brain. A recent review by Cosgrove [41] covers many of these agents.

Two types of agents are particularly important to discuss because they have recently become available or should become available very soon. These are the amyloid imaging agents florbetapir (AV-45) and Pittsburgh compound $\mathrm{B}$, and ${ }^{123} \mathrm{I}$-ioflupane (DaTscan).

Ioflupane has a high binding affinity for presynaptic dopamine transporters and is useful in the diagnosis and follow-up of patients with various movement disorders, particularly Parkinson's disease. In normal subjects, there is excellent uptake in the caudate and putamen, but in patients with Parkinson's disease, there is diminished and often asymmetric uptake [42]. The agent was released for marketing in the United States in March 2011 and is only beginning to be used clinically.

The amyloid imaging agents have been developed to aid in the diagnosis of Alzheimer's disease and to provide a quantitative measure of brain amyloid in subjects receiving treatment intended to reduce the brain amyloid burden. ${ }^{11} \mathrm{C}$-labeled Pittsburgh compound B was developed in the early 2000s and has been shown to be an effective approach to diagnose Alzheimer's disease [43]. The other agent that is nearing approval is ${ }^{18} \mathrm{~F}$-florbetapir [44]. It has also been shown to effectively image amyloid in the brain. Approval has been delayed because of the wide inter- and intrareader variability in interpreting the images. Objective methodology is being developed to quantitate the uptake of both these agents, a step that appears to be necessary to provide reliable, consistent readings of the images and will be essential when these agents are used to follow the effects of treatment. Although considerable activity is currently under way to bring these agents to approval, it is unclear how they will be used until there is an effective treatment that reduces brain amyloid. The effort appears to be worthwhile since the imaging agents will be essential for the development of the treatments of brain amyloid. Once the therapeutic agents are developed, then the imaging agents will be used clinically.

\section{Heart}

${ }^{123}$ I-meta-iodobenzylguanidine (MIBG) is an analog of guanethidine and is taken up by the norepinephrine receptor. The uptake reflects the level of sympathetic neuronal activity in the heart. Low uptake in the myocardium is associated with an increased risk of ventricular arrhythmias and death. The major interest in this agent is its potential to risk-stratify heart failure patients who may benefit from an implantable cardioverter-defibrillator. These are very expensive devices and it is important to try to implant them only in patients who will benefit [45].

Neoangiogenesis is an important process in many embryologic, physiologic and pathologic situations. It can be 
triggered by hypoxia, which is probably the major mechanism of activation in injured myocardium and in tumors. Integrins are cell adhesion receptors that are involved in mediating migration of endothelial cells and in the regulation of endothelial cell growth. The $\alpha \mathrm{V} \beta 3$ integrin is one member of this class of receptors that is highly overexpressed during neoangiogenesis. It has been shown that the $\alpha \mathrm{V} \beta 3$ receptor can be specifically targeted with the three amino-acid sequence: arginine-glycineaspartate (RGD). Several different approaches have been explored to label the RGD sequence. One of the approaches uses ${ }^{123}$ I-galacto-RGD. This agent has been used in a swine model to assess the effect of angiogenesis therapy with vascular endothelial growth factor [46]. Little work has been done in humans, but this approach may be very useful as new drugs are developed to improve angiogenesis in the heart after infarction [47].

Other areas of research in cardiac molecular imaging with radiopharmaceuticals include imaging of adenosine receptors [48], opioid receptors [49], muscarinic receptors [50], and studies of pre- and postsynaptic cardiac $\beta$ adrenergic function [51]. Thus far, these studies have been done in limited centers and are further away from clinical applicability than the agents discussed above.

\section{Liver}

99mTc-galactosyl-neoglycoalbumin specifically binds to hepatic binding protein, and provides a measure of the mass of healthy normal hepatocytes [52]. It has been used to differentiate focal nodular hyperplasia from malignant liver lesions, evaluation of liver function in liver transplant recipients, and for assessing prognosis in hepatic failure.

\section{Tumor}

\section{Somatostatin Receptor}

Octreotide, an eight amino-acid oligopeptide labeled with ${ }^{111} \mathrm{In}$, has been a very effective agent for imaging a wide range of neuroendocrine tumors by targeting the somatostatin receptor. The tumor types studied successfully with octreotide include growth hormone-secreting pituitary tumors, endocrine pancreatic tumors, carcinoid, paraganglioma, medullary thyroid carcinoma, pheochromocytomas, small-cell lung carcinoma, neuroblastoma, meningioma, and Merkel cell tumors [53].

Many of these tumors are relatively slow growing and can be treated effectively with a nonradioactive version of the same octapeptide, or with various other analogs that are labeled with ${ }^{90} \mathrm{Y}$ or ${ }^{177} \mathrm{Lu}$. These isotopes are both $\beta$ emitters and can deliver very high radiation doses to these tumors [54].

A wide variety of different analogs of somatostatin have been investigated and have been found to have different binding affinities for the five different somatostatin receptor subtypes. Recently, several of the analogs have been labeled with ${ }^{68} \mathrm{Ga}$ for PET imaging in humans. The chelation group DOTA (1,4,7,10-tetraazacyclododecane$1,4,7,10$-tetraacetic acid) is commonly used to link the ${ }^{68} \mathrm{Ga}$ to the oligopeptide somatostatin analog. Thus, the various agents are designated as: DOTAOC, DOTATOC, DOTATATE, DOTANOC, and DOTABOC [55]. Undoubtedly other DOTA-linked analogs are under development.

${ }^{68} \mathrm{Ga}$ PET imaging with these analogs is remarkably superior to SPECT imaging with ${ }^{111}$ In-octreotide because of the shorter interval between injection and imaging, lower radiation dose, higher target-to-background ratio and higher resolution.

\section{${ }^{123}$ I-Metaiodobenzylguanidine}

As described above, ${ }^{123}$ I-MIBG is taken up by the norepinephrine receptor. It is particularly useful in the diagnosis of pheochromocytoma, both benign and malignant [56]. It is also useful in staging patients with neuroblastoma, and ${ }^{131} \mathrm{I}-\mathrm{MIBG}$ has been used in the treatment of neuroblastoma, as well as pheochromocytoma. Since MIBG visualizes pheochromocytoma so effectively, it would seem that it should be equally successful in paraganglioma; however, ${ }^{111}$ In-octreotide actually works much better [57]. This suggests significantly different metabolisms in the two diseases.

A major problem with the practical use of MIBG is the large number of medications that interfere with its uptake [58]. Some (but not all) of the more common drugs include many antihypertensives, labetalol, reserpine, calcium channel blockers, tricyclic antidepressants, sympathomimetics (nasal decongestants), phenylephrine, pseudoephedrine, ephedrine and cocaine. This can often make it impractical to actually obtain useful MIBG images.

\section{Prostate-Specific Membrane Antigen}

Capromab pendetide (Prostascint) is a monoclonal antibody directed against prostate-specific membrane antigen (PSMA). It is the only approved, widely available radiotracer for the evaluation of prostate cancer. Unfortunately, the antibody is directed against a portion of PSMA that is intracellular, so it presumably is only targeting dead or dying prostate cancer cells. Prostascint con- 
tinues to be used even though it has a relatively low targetto-background ratio because no other agents are currently available [59].

The need for an effective prostate cancer-imaging agent has encouraged several research groups and companies to look for a better agent. J591 is another antibody that targets PSMA, this time to an extracellular site. It appears to have better imaging characteristics than Prostascint, and it also been studied for its use in treating prostate cancer, using ${ }^{177} \mathrm{Lu}$-labeled J591 [60].

Several other approaches for imaging prostate cancer are being explored [61]. These include agents directed against the androgen receptor [62], and against gastrinreleasing peptide receptors, typically using analogs of bombesin [63]. Acetate and choline are also effective imaging agents for prostate cancer, as discussed above.

\section{Neoangiogenesis-Imaging Agents}

The RGD-based agents used in cardiac imaging can also be used for imaging neoangiogenesis in tumors [64]. There are a number of newer receptor-based anti-tumor agents, such as bevacizumab, that are specifically directed against vascular endothelial growth factor-A. The RGD imaging agents should be particularly useful in monitoring the receptor occupancy, and presumably predicting the efficacy of such anti-angiogenesis drugs.

\section{Melanocortin Receptor}

The melanocortin type 1 receptor is an attractive molecular target for the diagnosis of metastatic melanoma and also for possible radiotherapy using $\beta$-emitting isotopes as the label. Most of the agents that have been studied recently are peptides labeled with radiometals such as ${ }^{111} \mathrm{In},{ }^{68} \mathrm{Ga}$, and ${ }^{64} \mathrm{Cu}[65,66]$, as well as with ${ }^{18} \mathrm{~F}[67]$. The published papers describe successful preclinical studies in animals, and human trials are beginning to get under way.

\section{Carbonic Anhydrase IX}

A complex sequence of events occurs associated with tumor hypoxia, starting with activation of hypoxia-inducible factor $1 \alpha$ (HIF-1 $\alpha)$, which, in turn, activates a large number of genes that assist the cells to tolerate the hypoxic environment. One of the activated genes is for carbonic anhydrase type 9 (CA-IX). Recently, phase 3 clinical trials have been completed for an ${ }^{124}$ I-labeled antibody (cG250) directed against CA-IX for imaging renal cell cancer. It is likely to be approved in the near future. The published results and images suggest that this agent is likely to be useful for the diagnosis and staging of renal cell carcinoma. It is also known that there are elevated levels of CA-IX in other tumors, including carcinomas of the uterine cervix, esophagus, lung, breast, brain and vulva, which suggests that the agent might find wider utility than only in renal cell cancer [68].

Once this agent is approved, it will be the first approved ${ }^{124}$ I-labeled agent. ${ }^{124} \mathrm{I}$ is a positron emitter with a half-life of 4.18 days. The long half-life is useful for antibody imaging because the kinetics are relatively slow, with imaging taking place 5 days after injection.

\section{CD-20 Antigen}

Most types of lymphoma overexpress the CD-20 antigen. The monoclonal antibody, rituximab, avidly binds to the CD-20 antigen on normal and malignant B lymphocytes. It produces antibody-dependent cell- and complement-mediated cytotoxicity in these cells. The nonradioactive drug has become a major part of the therapy of lymphoma. It was recognized that since rituximab effectively targeted lymphoma, it should be possible to label it with $\beta$-emitting radioisotopes to augment the treatment.

Two radiolabeled versions of CD-20 are available, ${ }^{131} \mathrm{I}$ tositumomab (Bexxar) and ${ }^{90}$ Y-ibritumomab tiuxetan (Zevalin). Clinical trials with these agents have shown that they improve survival in most of the groups studied [69]. The agents are widely available, but are not used as much as expected because of a number of logistic, financial and practical issues. They both illustrate the potential for the use of radiolabeled antibodies in the therapy of cancer, but have also shown that it can be challenging to introduce a new approach that cuts across multiple medical specialties [70].

\section{Cell Trafficking}

Many of the cells in the body move from one site to another to perform a variety of vital functions. One of the most obvious is the migration of granulocytes to sites of infection, but many other cells, such as T lymphocytes, stem cells and macrophages, also migrate. These movements can be observed and quantitated by either direct or indirect cell labeling.

\section{Directly Labeled White Blood Cells}

The clinically useful labels for white blood cells are ${ }^{111}$ In-oxine and ${ }^{99 \mathrm{~m}} \mathrm{Tc}-$-hexamethylpropyleneamine oxime (HMPAO) [71]. Both of these agents are nonspecific in terms of the cell type that is labeled. The method requires separation of the relevant cells, followed by addi- 
tion of the labeling agent, incubation, and then washing to remove any unbound label. White blood cells are usually separated by sedimentation of anticoagulated blood, with careful pipetting of the buffy coat. If the plasma is pipetted instead, then platelets will be labeled [72]. If more advanced separation strategies are used, it is possible to specifically label lymphocytes [73], monocytes [74], or eosinophils [75]. Imaging is generally done a few hours after re-injection. The major pitfall with this method [76] is that the cells can be damaged during the separation and labeling procedure, and may not be viable at the time of reinjection.

\section{Indirectly Labeled Cells}

An elegant and very effective way to label cells is to transfect them with a gene that makes the cell imageable [77]. Most of the effort using this approach has been with the iodine symporter gene [78]. After cells have been transfected with the symporter gene, using an adenovirus as the carrier, they can be imaged by injecting any of the isotopes of iodine or ${ }^{99 \mathrm{~m}} \mathrm{Tc}$ pertechnetate. This approach has been used recently to study the trafficking of macrophages in humans [79].

Reporter gene imaging can also be used to image the activity of other genes, both for imaging cell trafficking, but also to monitor the efficacy of gene therapy [80]. A recent example of such a study in humans is the imaging of herpes simplex virus 1 thymidine kinase activity in a patient with glioma. herpes simplex virus 1 thymidine kinase is a 'suicide gene' that results in death of transfected cells when exposed to gancyclovir. It can be imaged with ${ }^{18} \mathrm{~F}$-fluoro-3-(hydroxymethyl)butyl]guanine [81].

\section{Conclusion}

Although the term 'molecular imaging' is relatively new, the concept has been in existence since at least the beginning of nuclear medicine with radioiodine therapy of thyroid disease. The wide variety of metabolic and receptor-based agents used in molecular imaging today illustrates the potential of this approach.

Molecular imaging has the potential to become the critical methodology in the development of personalized medicine. As the therapeutic agents become more sophisticated and more tightly targeted against specific membrane targets and metabolic pathways, it will become increasingly important to be able to identify the presence of the targets and the changes in metabolism by in vivo imaging. This is the enormous potential of molecular imaging.

\section{References}

1 MI_Gateway: The Newsletter of the SNM Molecular Imaging Center of Excellence. 2007, p 1.

-2 Mintun MA, Dennis DR, Welch MJ, Mathias CJ, Schuster DP: Measurements of pulmonary vascular permeability with PET and gallium-68 transferrin. J Nucl Med 1987;28: 1704-1716.

-3 Gomez-Rio M, Rodriguez-Fernandez A, Ramos-Font C, Lopez-Ramirez E, Llamas Elvira JM: Diagnostic accuracy of 201 Thallium-SPECT and 18F-FDG-PET in the clinical assessment of glioma recurrence. Eur J Nucl Med Mol Imaging 2008;35:966975.

$\checkmark 4$ Di Carli MF, Dorbala S, Meserve J, El Fakhri G, Sitek A, Moore SC: Clinical myocardial perfusion PET/CT. J Nucl Med 2007;48:783793.

-5 Nishiyama H, Sodd VJ, Adolph RJ, Saenger EL, Lewis JT, Gabel M: Intercomparison of myocardial imaging agents: ${ }^{201} \mathrm{Ti},{ }^{129} \mathrm{Cs},{ }^{43} \mathrm{~K}$, and ${ }^{81} \mathrm{Rb}$. J Nucl Med 1976;17:880-889.

6 Paes FM, Serafini AN: Systemic metabolic radiopharmaceutical therapy in the treatment of metastatic bone pain. Semin Nucl Med 2010;40:89-104.
7 Boogers MJ, Borleffs CJ, Henneman MM, van Bommel RJ, van Ramshorst J, Boersma E, Dibbets-Schneider P, Stokkel MP, van der Wall EE, et al: Cardiac sympathetic denervation assessed with 123-iodine metaiodobenzylguanidine imaging predicts ventricular arrhythmias in implantable cardioverter-defibrillator patients. J Am Coll Cardiol 2010; 55:2769-2777.

8 Mari C, Strauss WH: Detection and characterization of hibernating myocardium. Nucl Med Commun 2002;23:311-322.

-9 Messina SA, Aras O, Dilsizian V: Delayed recovery of fatty acid metabolism after transient myocardial ischemia: a potential imaging target for 'ischemic memory'. Curr Cardiol Rep 2007;9:159-165.

10 Reivich M, Kuhl D, Wolf A, Greenberg J, Phelps M, Ido T, Casella V, Fowler J, Hoffman E, et al: The $\left[{ }^{18} \mathrm{~F}\right]$ fluorodeoxyglucose method for the measurement of local cerebral glucose utilization in man. Circ Res 1979;44:127-137.

11 Goffin K, Dedeurwaerdere S, Van Laere K, Van Paesschen W: Neuronuclear assessment of patients with epilepsy. Semin Nucl Med 2008;38:227-239.
12 Silverman DH, Small GW, Chang CY, Lu CS, Kung De Aburto MA, Chen W, Czernin J, Rapoport SI, Pietrini P, et al: Positron emission tomography in evaluation of dementia: Regional brain metabolism and long-term outcome. JAMA 2001;286:2120-2127.

13 Jones AG, Francis MD, Davis MA: Bone scanning: radionuclidic reaction mechanisms. Semin Nucl Med 1976;6:3-18.

14 Ronai P, Winchell HS, Anger HO: Skeletal survey for metastatic tumors of bone usine ${ }^{18} \mathrm{~F}$ and ${ }^{85} \mathrm{Sr}$ with scintillation camera and whole-body scanner. J Nucl Med 1968;9:517522.

15 Grant FD, Fahey FH, Packard AB, Davis RT, Alavi A, Treves ST: Skeletal PET with ${ }^{18} \mathrm{~F}$ fluoride: applying new technology to an old tracer. J Nucl Med 2008;49:68-78.

16 de Graaf W, Bennink RJ, Vetelainen R, van Gulik TM: Nuclear imaging techniques for the assessment of hepatic function in liver surgery and transplantation. J Nucl Med 2010;51:742-752.

17 Chudhuri TK, Evans TC: Autoradiographic studies of distribution in the liver of ${ }^{198} \mathrm{Au}$ and ${ }^{99 \mathrm{~m}} \mathrm{Tc}$-sulfur colloids. Radiology 1973 ; 109:633-637. 
18 Sugiu T, Hamazaki K, Sakumoto S, Mimura $\mathrm{H}$, Tanaka N: Experimental evaluation of hepatic functional reserve using 111In colloid for clinical application. In vivo 1998;12:315319.

19 Itoh K: ${ }^{99 \mathrm{~m}} \mathrm{Tc}-\mathrm{MAG} 3$ : review of pharmacokinetics, clinical application to renal diseases and quantification of renal function. Ann Nucl Med 2001;15:179-190.

20 Moran JK: Technetium-99m-EC and other potential new agents in renal nuclear medicine. Semin Nucl Med 1999;29:91-101.

-21 Taylor AT, Lipowska M, Hansen L, Malveaux E, Marzilli LG: ${ }^{99 \mathrm{~m}}$ Tc-MAEC complexes: new renal radiopharmaceuticals combining characteristics of ${ }^{99 \mathrm{~m}} \mathrm{Tc}-\mathrm{MAG} 3$ and ${ }^{99 \mathrm{~m}} \mathrm{Tc}$ EC. J Nucl Med 2004;45:885-891.

-22 Piepsz A, Blaufox MD, Gordon I, Granerus G, Majd M, O’Reilly P, Rosenberg AR, Rossleigh MA, Sixt R: Consensus on renal cortical scintigraphy in children with urinary tract infection. Semin Nucl Med 1999;29: 160-174.

-23 Agnew JE, Maze M, Mitchell CJ: Pancreatic scanning. Br J Radiol 1976;49:979-995.

-24 Wu Z, Kandeel F: Radionuclide probes for molecular imaging of pancreatic $\beta$-cells. Adv Drug Deliv Rev 2010;62:1125-1138.

25 Ichise M, Harris PE: Imaging of $\beta$-cell mass and function. J Nucl Med 2010;51:10011004.

26 Potchen EJ, Wilson RE, Dealy JB Jr: External parathyroid scanning with Se75 selenomethionine. Ann Surg 1965;162:492504.

27 Oksuz MO, Dittmann H, Wicke C, Mussig K, Bares R, Pfannenberg C, Eschmann SM: Accuracy of parathyroid imaging: a comparison of planar scintigraphy, SPECT, SPECT$\mathrm{CT}$ and $\mathrm{C}-11$ methionine PET for the detection of parathyroid adenomas and glandular hyperplasia. Diagn Interv Radiol DOI: 10.4261/1305-3825.DIR.3486-10.1.

-28 Freitas JE GR, Thrall JH, Gross MD, Swanson DP, Beierwaltes WH: Adrenal imaging with iodomethyl-norcholesterol (I-131) in primary aldosteronism. J Nucl Med 1979;20: 7-10.

29 Langer A: A systematic review of PET and PET/CT in oncology: a way to personalize cancer treatment in a cost-effective manner? BMC Health Serv Res 2010;10:283.

- 30 Sohn HJ, Yang YJ, Ryu JS, Oh SJ, Im KC, Moon DH, Lee DH, Suh C, Lee JS, et al: $\left[{ }^{18} \mathrm{~F}\right]$ Fluorothymidine positron emission tomography before and 7 days after gefitinib treatment predicts response in patients with advanced adenocarcinoma of the lung. Cancer Res 2008;14:7423-7429.

- 31 Jadvar H: Prostate cancer: PET with ${ }^{18} \mathrm{~F}$ FDG, ${ }^{18} \mathrm{~F}$ - or $11 \mathrm{C}$-acetate, and ${ }^{18} \mathrm{~F}$ - or ${ }^{11} \mathrm{C}$ choline. J Nucl Med 2011;52:81-89.

- 32 Lindhe O, Sun A, Ulin J, Rahman O, Langstrom B, Sorensen J: $\left[{ }^{18} \mathrm{~F}\right]$ Fluoroacetate is not a functional analogue of $\left[{ }^{11} \mathrm{C}\right]$ acetate in normal physiology. Eur J Nucl Med Mol Imaging 2009;36:1453-1459.
33 Matsuo M, Miwa K, Shinoda J, Kako N, Nishibori H, Sakurai K, Yano H, Iwama T, Kanematsu M: Target definition by C11-methionine-PET for the radiotherapy of brain metastases. Int J Radiat Oncol Biol Phys 2009;74:714-722.

34 Terakawa Y, Tsuyuguchi N, Iwai Y, Yamanaka K, Higashiyama S, Takami T, Ohata K: Diagnostic accuracy of ${ }^{11} \mathrm{C}$-methionine PET for differentiation of recurrent brain tumors from radiation necrosis after radiotherapy. J Nucl Med 2008;49:694-699.

35 Becherer A, Karanikas G, Szabo M, Zettinig G, Asenbaum S, Marosi C, Henk C, Wunderbaldinger $\mathrm{P}$, Czech T, et al: Brain tumour imaging with PET: a comparison between $[18 \mathrm{~F}]$ fluorodopa and $\left[{ }^{11} \mathrm{C}\right]$ methionine. Eur J Nucl Med Mol Imaging 2003;30:1561-1567.

- 36 Hubner KF, Thie JA, Smith GT, Kabalka GW, Keller IB, Kliefoth AB, Campbell SK, Buonocore E: Positron emission tomography (PET) with 1-aminocyclobutane-1- $\left[{ }^{11} \mathrm{C}\right]$ carboxylic acid $\left(1-\left[{ }^{11} \mathrm{C}\right]-\mathrm{ACBC}\right)$ for detecting recurrent brain tumors. Clin Positron Imaging 1998;1: 165-173.

37 Mease RC: Radionuclide based imaging of prostate cancer. Curr Top Med Chem 2010; 10:1600-1616.

38 Mees G, Dierckx R, Vangestel C, Van de Wiele C: Molecular imaging of hypoxia with radiolabelled agents. Eur J Nucl Med Mol Imaging 2009;36:1674-1686.

39 Holland JP, Lewis JS, Dehdashti F: Assessing tumor hypoxia by positron emission tomography with Cu-ATSM. Q J Nucl Med Mol Imaging 2009;53:193-200.

40 Dearling JL, Packard AB: Some thoughts on the mechanism of cellular trapping of Cu(II)-ATSM. Nucl Med Biol 2010;37:237243.

41 Cosgrove KP: Imaging receptor changes in human drug abusers. Curr Top Behav Neurosci 2010;3:199-217.

42 Vlaar AM, de Nijs T, Kessels AG, Vreeling FW, Winogrodzka A, Mess WH, Tromp SC, van Kroonenburgh MJ, Weber WE: Diagnostic value of ${ }^{123}$ I-ioflupane and ${ }^{123} \mathrm{I}$-iodobenzamide SPECT scans in 248 patients with parkinsonian syndromes. Eur Neurol 2008; 59:258-266.

43 Rowe CC, Ng S, Ackermann U, Gong SJ, Pike K, Savage G, Cowie TF, Dickinson KL, Maruff $P$, et al: Imaging $\beta$-amyloid burden in aging and dementia. Neurology 2007;68: $1718-1725$.

44 Clark CM, Schneider JA, Bedell BJ, Beach TG, Bilker WB, Mintun MA, Pontecorvo MJ Hefti F, Carpenter AP, et al: Use of florbetapir-PET for imaging $\beta$-amyloid pathology. JAMA 2011;305:275-283.

45 Ji SY, Travin MI: Radionuclide imaging of cardiac autonomic innervation. J Nucl Cardiol 2010;17:655-666.

46 Johnson LL, Schofield L, Donahay T, Bouchard M, Poppas A, Haubner R: Radiolabeled arginine-glycine-aspartic acid peptides to image angiogenesis in swine model of hibernating myocardium. JACC Cardiovasc Imaging 2008;1:500-510.

47 Sinusas AJ: Targeted imaging offers advantages over physiological imaging for evaluation of angiogenic therapy. JACC Cardiovasc Imaging 2008;1:511-514.

- 48 Herzog H, Elmenhorst D, Winz O, Bauer A Biodistribution and radiation dosimetry of the $\mathrm{A}_{1}$-adenosine receptor ligand ${ }^{18} \mathrm{~F}$-CPFPX determined from human whole-body PET. Eur J Nucl Med Mol Imaging 2008;35:14991506.

49 Villemagne PS, Dannals RF, Ravert HT, Frost JJ: PET imaging of human cardiac opioid receptors. Eur J Nucl Med Mol Imaging 2002;29:1385-1388

50 Mazzadi AN, Pineau J, Costes N, Le Bars D, Bonnefoi F, Croisille P, Porcher R, Chevalier $\mathrm{P}$ : Muscarinic receptor upregulation in patients with myocardial infarction: a new paradigm. Circ Cardiovasc Imaging 2009;2: 365-372.

51 Link JM, Stratton JR, Levy W, Poole JE, Shoner SC, Stuetzle W, Caldwell JH: PET measures of pre- and post-synaptic cardiac $\beta$-adrenergic function. Nucl Med Biol 2003; 30:795-803.

52 Kudo M, Vera DR, Stadalnik RC, Esquivel CO, Trudeau WL, Ikekubo K, Todo A: Measurement of functioning hepatocyte mass via [99m Tc] galactosyl-neoglycoalbumin. Dig Dis Sci 1993;38:2183-2188.

53 Kaltsas G, Rockall A, Papadogias D, Reznek $\mathrm{R}$, Grossman AB: Recent advances in radiological and radionuclide imaging and therapy of neuroendocrine tumours. Eur J Endocrinol 2004;151:15-27.

54 Bodei L, Ferone D, Grana CM, Cremonesi M, Signore A, Dierckx RA, Paganelli G: Peptide receptor therapies in neuroendocrine tumors. J Endocrinol Invest 2009;32:360-369.

55 Ambrosini V, Tomassetti P, Franchi R, Fanti $S$ : Imaging of NETs with PET radiopharmaceuticals. Q J Nucl Med Mol Imaging 2010; 54:16-23.

56 Jacobson AF, Deng H, Lombard J, Lessig HJ, Black RR: ${ }^{123}$ I-meta-iodobenzylguanidine scintigraphy for the detection of neuroblastoma and pheochromocytoma: results of a meta-analysis. J Clin Endocrinol Metab 2010;95:2596-2606.

57 Koopmans KP, Jager PL, Kema IP, Kerstens MN, Albers F, Dullaart RP: ${ }^{111} \mathrm{In}$-octreotide is superior to ${ }^{123}$ I-metaiodobenzylguanidine for scintigraphic detection of head and neck paragangliomas. J Nucl Med 2008;49:1232-1237.

58 Bombardieri E, Aktolun C, Baum RP, BishofDelaloye A, Buscombe J, Chatal JF, Maffioli L, Moncayo R, Mortelmans L, et al: ${ }^{131} \mathrm{I} /{ }^{123} \mathrm{I}$ metaiodobenzylguanidine (MIBG) scintigraphy: procedure guidelines for tumour imaging. Eur J Nucl Med Mol Imaging 2003; 30:BP132-BP139.

59 Haseman MK, Rosenthal SA, Polascik TJ: Capromab Pendetide imaging of prostate cancer. Cancer Biother Radiopharm 2000; $15: 131-140$ 
60 Bander NH, Milowsky MI, Nanus DM, Kostakoglu L, Vallabhajosula S, Goldsmith SJ: Phase I trial of 177-lutetium-labeled J591, a monoclonal antibody to prostate-specific membrane antigen, in patients with androgen-independent prostate cancer. J Clin Oncol 2005;23:4591-4601.

61 Hong H, Zhang Y, Sun J, Cai W: Positron emission tomography imaging of prostate cancer. Amino Acids 2010;39:11-27.

-62 Fox JJ, Morris MJ, Larson SM, Schoder H, Scher HI: Developing imaging strategies for castration resistant prostate cancer. Acta Oncol 2011;50(suppl 1):39-48.

-63 Yang M, Gao H, Zhou Y, Ma Y, Quan Q, Lang L, Chen K, Niu G, Yan Y, et al: F-labeled GRPR agonists and antagonists: a comparative study in prostate cancer imaging. Theranostics 2011;1:220-229.

-64 Haubner R, Beer AJ, Wang H, Chen X: Positron emission tomography tracers for imaging angiogenesis. Eur J Nucl Med Mol Imaging 2010;37(suppl 1):S86-S103.

-65 Wei L, Zhang X, Gallazzi F, Miao Y, Jin X, Brechbiel MW, Xu H, Clifford T, Welch MJ, et al: Melanoma imaging using ${ }^{111} \mathrm{In}-,{ }^{86} \mathrm{Y}-$ and ${ }^{68} \mathrm{Ga}$-labeled CHX-A"-Re(Arg11)CC MSH. Nucl Med Biol 2009;36:345-354.

-66 Cheng Z, Xiong Z, Subbarayan M, Chen X, Gambhir SS: 64-Cu-labeled $\alpha$-melanocytestimulating hormone analog for microPET imaging of melanocortin 1 receptor expression. Bioconjug Chem 2007; 18:765-772.
67 Ren G, Liu Z, Miao Z, Liu H, Subbarayan M, Chin FT, Zhang L, Gambhir SS, Cheng Z: PET of malignant melanoma using ${ }^{18} \mathrm{~F}-\mathrm{la}$ beled metallopeptides. J Nucl Med 2009;50: 1865-1872.

68 Stillebroer AB, Mulders PF, Boerman OC, Oyen WJ, Oosterwijk E: Carbonic anhydrase IX in renal cell carcinoma: implications for prognosis, diagnosis, and therapy. Eur Urol 2010;58:75-83.

69 Davies AJ: Radioimmunotherapy for B-cell lymphoma: Y90 ibritumomab tiuxetan and I(131) tositumomab. Oncogene 2007;26: 3614-3628.

70 Lin FI, Iagaru A: Current concepts and future directions in radioimmunotherapy. Curr Drug Discov Tech 2010;7:253-262.

71 Mountford PJ, Kettle AG, O’Doherty MJ, Coakley AJ: Comparison of technetium99m-HM-PAO leukocytes with indium-111oxine leukocytes for localizing intraabdominal sepsis. J Nucl Med 1990;31:311-315.

72 Peters AM, Lavender JP: Platelet kinetics with indium-111 platelets: comparison with chromium-51 platelets. Semin Thromb Hemost 1983;9:100-114.

73 Fulgenzi A, Casati R, Colombo FR, Gasparini M, Ferrero E, Bondanza A, Gerundini P, Ferrero ME: Distribution of ${ }^{99 \mathrm{~m}} \mathrm{Tc}$-labeled lymphocytes in control and inflamed rats. Nucl Med Biol 2004;31:631-638.

74 van Hemert FJ, Thurlings R, Dohmen SE, Voermans C, Tak PP, van Eck-Smit BL, Bennink RJ: Labeling of autologous monocytes with ${ }^{99 \mathrm{~m}} \mathrm{Tc}-\mathrm{HMPAO}$ at very high specific radioactivity. Nucl Med Biol 2007;34:933-938.
5 Runge VM, Rand TH, Clanton JA, Jones JP, Colley DG, Partain CL, James AE Jr: 111Inlabeled eosinophils: localization of inflammatory lesions and parasitic infections in mice. Int J Nucl Med Biol 1985;12:135-144.

76 Thakur ML, Seifert CL, Madsen MT, McKenney SM, Desai AG, Park CH: Neutrophil labeling: problems and pitfalls. Semin Nucl Med 1984; 14:107-117.

77 Ottobrini L, Martelli C, Trabattoni DL, Clerici $M$, Lucignani $G$ : In vivo imaging of immune cell trafficking in cancer. Eur J Nucl Med Mol Imaging 2011;38:949-968.

78 Chung JK: Sodium iodide symporter: its role in nuclear medicine. J Nucl Med 2002;43: $1188-1200$

79 Seo JH, Jeon YH, Lee YJ, Yoon GS, Won DI, Ha JH, Jeong SY, Lee SW, Ahn BC, et al: Trafficking macrophage migration using reporter gene imaging with human sodium iodide symporter in animal models of inflammation. J Nucl Med 2010;51:1637-1643.

-80 Serganova I, Ponomarev V, Blasberg R: Human reporter genes: potential use in clinical studies. Nucl Med Biol 2007;34:791-807.

81 Yaghoubi SS, Jensen MC, Satyamurthy N, Budhiraja S, Paik D, Czernin J, Gambhir SS: Noninvasive detection of therapeutic cytolytic T cells with ${ }^{18} \mathrm{~F}$-FHBG PET in a patient with glioma. Nat Clin Pract Oncol 2009;6: 53-58. 